\title{
On Hybridization of some Species of Salix. II.
}

\author{
BY
}

\section{S. IKENO, F.M.L.S.}

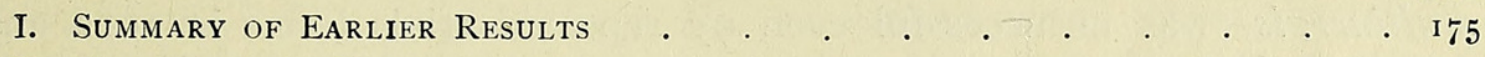

II. Formation of Hybrids-

I. General and $F_{1}$ Generation . . . . . . . . . 176

2. $F_{2}$ Generation . • . . . . . . . . . . . 178

3. Back-crosses . . . . . . . . . . . . . I79

4. Potency . . . . . . . . . . . . . . . I $\mathrm{I}_{\mathrm{I}}$

III. Formation of Parental Form . . . . . . . . . . . . . 183

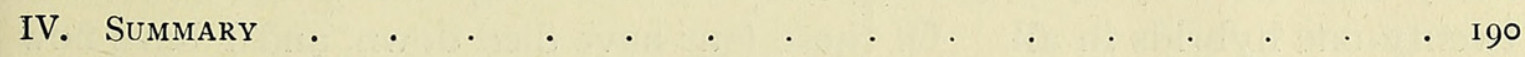

I. Summary of Earlier Results.

FIRST I will briefly recapitulate here what I have stated in my former paper concerning the same subject, ${ }^{1}$ in so far as it is related to the present communication, because this will conduce much to clearness.

The hybridizations between two Japanese species of Salix, viz. gracilistyla and multinervis, were done in I9I0 and I9II. The character which sharply distinguishes them is among others the hairy condition of their catkin : that of the former is characterized by being densely covered with greyish hairs, whilst that of the latter is very sparingly hairy (cf. Ikeno, l. c., Pl. I, Figs. I-2). The cross multinervis $\times$ gracilistyla donie in I 910 has given rise to fourteen $F_{1}$ hybrids. The latter were not uniform: eleven were provided with catkins densely hairy like gracilistyla (hence called plants of $G$-type), and three with catkins sparingly hairy like multinervis (hence called plants of $M$-type). It is to be noticed that each of the two parents was examined in respect to its genetical purity by means of fertilization inter se, and found to breed true to its respective type. The fertilization between male and female G-type has given rise in $F_{2}$ to many G-types and a few M-types, and that between male and female M-type to many M-types and a few G-types, while that between male G-type and female M-type has produced both types in almost equal number. I have tried to explain the formation of two types of progeny in $F_{1}$, despite the apparent genetical purity of both parents, by the action of invisible factors.

1 Journ. of Genetics, I91 8, vol. viii, pp. $35-58$.

[Annals of Botany, Vol. XXXVI. No. CXLII. April, 1922.] 
The result of the same hybridization done in I9I I was quite different from that of I9I0. It has given rise to almost fifty plants which were not hybrids, as was expected, but multinervis, i. e. identical with the motherplant; all were found to be female.

\section{Formation of Hybrids.}

\section{General and $F_{1}$ Generation.}

Though, as stated above, multinervis $\times$ gracilistyla has always given rise to a certain number of progeny, its reciprocal cross, i. e. gracilistyla $\times$ multinervis, was unsuccessful even by repeated trials (done in I9I2 and I918), and I stated in my former paper that this hybridization is wellnigh impossible. ${ }^{1}$ This conclusion was, however, rather hasty. In 1919 I once more tried this operation, and was much astonished to see that this time I obtained success, though scanty. I have pollinated many ears, but only three have given some seedlings and I have obtained twenty-one hybrids in all. Of these four have died down, and I have now seventeen planted in my garden; they have not flowered yet, except two, each of which has borne G-type female catkins. So far as I am able to judge by their leaves, the remaining fifteen are certainly hybrids exactly similar to those ex multinervis $\times$ gracilistyla. The definite classification of all of them according to the nature of their catkins is thus still impossible, and they are consequently of not much use in my present experiment. I wish merely to point out the fact that gracilistyla $\times$ multinervis may be successful, though very rarely.

From multinervis $\times$ gracilistyla carried on in 1910 I got only fourteen hybrids. As this number is very small I repeated the same hybridization in 1918 , and obtained many more offspring. Though seven of them have not yet produced flowers, those with flowers may be classified as follows :

TABLE I.

\begin{tabular}{|c|c|c|c|c|c|c|c|c|c|c|c|}
\hline \multirow[b]{2}{*}{$\begin{array}{l}\text { No. of } \\
\text { Cross. }\end{array}$} & \multicolumn{4}{|c|}{ Progeny. } & \multirow[b]{2}{*}{ Totals. } & \multirow[b]{2}{*}{$\begin{array}{l}\text { No. of } \\
\text { Cross. }\end{array}$} & \multicolumn{5}{|c|}{ Progeny. } \\
\hline & $G$-type. & M-type. & $G M$. & $M M$. & & & $G$-type. & $M$-type. & $G M$. & $M M$. & Totals. \\
\hline I & I & $\ldots$ & $\ldots$ & $\ldots$ & I & I 6 & I & $\ldots$ & $\ldots$ & $\ldots$ & I \\
\hline 2 & 5 & $\ldots$ & $\ldots$ & $\ldots$ & 5 & I 7 & $\ldots$ & I & $\ldots$ & $\ldots$ & I \\
\hline 4 & I & I & $\ldots$ & $\ldots$ & 2 & 18 & I & $\ldots$ & $\ldots$ & $\ldots$ & I \\
\hline 5 & I & $\ldots$ & $\ldots$ & $\ldots$ & I & I9 & I & $\ldots$ & $\ldots$ & $\ldots$ & I \\
\hline 6 & I & I & $\ldots$ & $\ldots$ & 2 & 20 & 2 & $\ldots$ & $\ldots$ & $\ldots$ & 2 \\
\hline 7 & 8 & $\ldots$ & $\ldots$ & $\ldots$ & 8 & 22 & I & $\ldots$ & $\ldots$ & $\ldots$ & I \\
\hline 8 & 4 & $\ldots$ & $\ldots$ & $\ldots$ & 4 & 23 & I & $\ldots$ & $\ldots$ & $\ldots$ & I \\
\hline 10 & 3 & 2 & $\ldots$ & $\ldots$ & 5 & 26 & 4 & $\ldots$ & $\ldots$ & I & 5 \\
\hline I I & 14 & $\ldots$ & I & $\ldots$ & I 5 & 28 & 4 & 3 & $\ldots$ & $\ldots$ & 7 \\
\hline 13 & 5 & I & $\ldots$ & $\ldots$ & 6 & 29 & $\ldots$ & $\ldots$ & $\ldots$ & I & I \\
\hline I4 & $\ldots$ & I & $\ldots$ & $\ldots$ & I & 30 & I & 1 & $\ldots$ & $\ldots$ & 2 \\
\hline & & & & & & Totals & 59 & II & I & 2 & 73 \\
\hline
\end{tabular}

${ }^{1}$ 1. c., p. 36. 
Each number in the above table includes plants derived from one catkin, and all catkins are taken from one tree. The table shows that very few plants are produced from each catkin-very often only one. This is first of all to be ascribed to the fact that each catkin is very poorly fertile, owing evidently to the great difficulty of the hybridization under discussion. Many more seeds were actually obtained than might be inferred from a simple inspection of the table ; many of them, however, failed to germinate, or else many seedlings perished in very young stages. In the table Nos. 3, 9, 12, 21, 24, 25, and 27 are wanting, because no adult plants were available from these pedigree numbers, owing to one of the two causes stated above. In one plant from No. II, ranked under the column GM, some branches bear G-type catkins, and others M-typed ones. Nos. 26 and 29 have each produced one female multinervis (placed under the column MM), to which I will refer later in this paper.

If we add together the $F_{1}$ hybrids from the crosses done in 1910 and I 918 we have :

TABLE II.

$\begin{array}{cccccc}\text { Year. } & \text { G-type. } & \text { M-type. } & \text { Multinervis. } & G M . & \text { Totals. } \\ \text { I910 } & \text { I I } & 3 & \ldots & \ldots & \text { 14 } \\ \text { I9I } 8 & 59 & \text { I } & 2 & \text { I } & 73 \\ \text { Totals } & 70 & \text { I } & 2 & \text { I } & 87 \\ \% & 83.3 & \text { 16.7 } & \ldots & \ldots & \ldots\end{array}$

If we take simple G- and M-types into consideration, the three remaining plants being left out of account, we have eighty-four offspring in all, composed of 83.3 per cent. G-types and 16.7 per cent. M-types.

The important question in respect to the hybridization under discussion is: Why will it yield the two types $\mathrm{G}$ and $\mathrm{M}$ already in $F_{1}$, despite the fact actually observed that each of the two parents breeds true respectively? Have we here to deal with a segregation? In my former paper I was led to the conclusion that we have in this case no segregation at all, and I tried to explain the appearance of two types in $F_{1}$, as well as the behaviour of the $F_{2}$ progeny, by the interference of invisible factors $X$ and $Y{ }^{1}$ The results of hybridizations between $F_{1}$ hybrids and either of the two parents (i. e. back-crossing) which were performed in I9I7 and I9I 8 served for testing the validity of my hypothesis. They were by no means particularly favourable for it. Especially, the results from G-type $F_{1} \times$ gracilistyla were contrary to my theoretical expectation : thus, if we denote by $X$ the factor which is able to cause $G g$ to develop to G-type, as was done in my former paper, ${ }^{2}$ we have G-type $F_{1}=X X G g$, and gracilistyla $=$ $G G$, and the cross $X X G g \times G G$ or $X X G g \times x \times G G$ should give rise to $2(X x G G+X x G g)$, i. e. to G-type progeny exclusively, which was not

$$
{ }^{1} \text { l. c., p. } 4^{8} \text { ff. } \quad 2 \text { l. c., p. } 5^{\circ} \mathrm{ff} \text {. }
$$


actually the case, inasmuch as I have got by this crossing not only G-type, but a certain number of M-types (see Table V, Expt. 6, below). Such a fact, as well as certain other reasons which would not be needed here to be enumerated, have led me to abandon my hypothesis, at least in the form in which it was expressed in my former paper. How can we then explain the phenomenon? For the reasons which I will not repeat here I was formerly unwilling to accept the 'imperfection of dominance ' for its explanation. ${ }^{1}$ But if the view of 'invisible factors' is to be abandoned, I think that there will be no better means than to resort to that of the 'imperfection of dominance', for the latter will explain most simply what we observe in respect to Salix hybrids; though I am still of the opinion that the interference of certain other factors, either visible or invisible and variously combined, may be the ultimate cause of this phenomenon. What is discussed below is consequently founded on the view of the 'imperfection of dominance'.

We have seen in Table $I$ that in $F_{1}$ of multinervis $\times$ gracilistyla we have 83.3 per cent. G-types and $16 \cdot 7$ per cent. M-types. We may regard the densely hairy condition of the catkin of gracilistyla to be dominant to the less hairy condition of that of multinervis as a rule, so that if we represent the former by $D$ and the latter by $R$, all $F_{1}$ hybrids will agree in being $D R$ genetically. The dominance here is not absolute; consequently only in the 83.3 per cent. is the dominant character observed, whilst in the remaining I 6.7 per cent. it fails, and lets the recessive character appear externally. In short, the G-type as well as the M-type progeny in $F_{1}$ are genotypically equal, though phaenotypically different; we have evidently no segregation in this generation. Moreover, Table I shows us that many numbers therein, each of which corresponds to one catkin, contain both G- and M-types. Hence we may conclude that not only one plant individual, but also even one and the same catkin, possesses at the same time both gametes where usual dominance of $D$ over $R$ prevails and those where it fails.

\section{2. $F_{2}$ Generation.}

In order to obtain the $F_{2}$ progeny I have carried on the three following crosses between the G-type and M-type progeny. ${ }^{2}$ The results are shown in the following table ${ }^{3}$ :

1 1. c., p. $4^{8}$.

2 Only in Expt. 3 is the male parent derived from $F_{2}$ (l. c., p. 42 ).

3 The number of progeny in Expts. $I$ and 2 is the same as in my former paper (1.c., pp. $4^{2-3}$ ), but that in Expt. 3 is a little larger, because I have added afterwards those plants which have borne flowers in 1919 and 1920 . In calculating the percentage the new type was not taken into account. 
TABLE III.

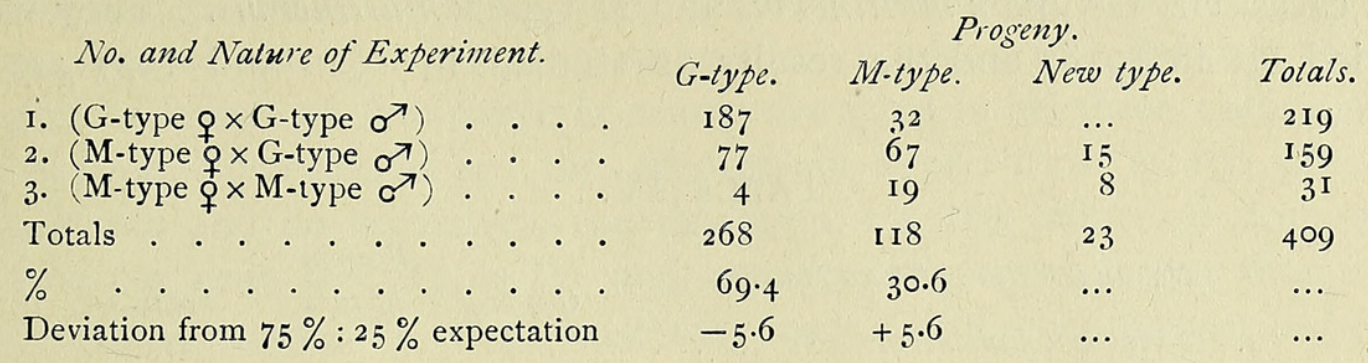

Plants ranked under the column 'New type' in the above table have their catkins very similar to those of M-type, but distinguished from the latter by their perfect non-hairiness (1.c., p. 44). In my former paper I stated my supposition that they will perhaps breed true in later generations. In order to confirm it many seeds of this type produced by fertilization inter se were sown in IgI8, and many germinated, but a large portion of the seedlings perished in the young stage, and I obtained only eleven adult plants. Of the latter two produced flowers in 1920 , and proved themselves to be the male and female plant respectively, and are quite similar to their parents externally. The remaining nine do not bear flowers yet. My supposition was thus confirmed, at least partially. The problem, whether they were produced by the so-called 'loss-mutation ' or by the new combination of certain factors, would not be definitely decided without further breeding experiments.

Since the crosses shown in Table III correspond to $D R \times D R$, we expect to get 75 per cent. $D$ and 25 per cent. $R$, if we are dealing here with the $3:$ I segregation. We have actually 69.4 per cent. G-types and 30.6 per cent. M-types, i.e. $\pm 5 \cdot 6$ per cent. deviation from this expectation. The deviation is positive on the side of M-type progeny, and this fact is evidently due to the imperfection of dominance: the $F_{2}$ progeny are to be represented genotypically by 25 per cent. $D D+50$ per cent. $D R+25$ per cent. $R R$; in the case under discussion in 5.6 per cent. out of 50 per cent. $D R$ the dominance failed, and the recessive character has made its appearance, or, in other words :

25 per cent. $D D+44.4$ per cent. $D R+5.6$ per cent. $(D R)+25$ per cent. $R R=(25+44 \cdot 4)$ per cent. G-type $+(5 \cdot 6+25)$ per cent. M-type $=69 \cdot 4$ per cent. G-type $+30 \cdot 6$ per cent. M-type.

$(D R)$ denotes the zygotes where the usual dominance fails.

In short, the segregation follows the $3: \mathrm{I}$ mode, and the deviation is due to the imperfection of dominance of the factor $D$ over $R$.

\section{Back-crosses.}

The results of back-crossing of $F_{1}$ hybrids by either of the two parents, i. e. $D R \times R$ or $D R \times D$, have fully confirmed those obtained in the $F_{1}$ as well as the $F_{2}$ generation. 
In respect to the back-cross $D R \times R$ we have to distinguish between two cases, viz. G-type $\times$ multinervis and M-type $\times$ multinervis. They were carried on in 1918 , and the results as studied in 1920 and 1921 are as follows :

\section{TABLE IV.}

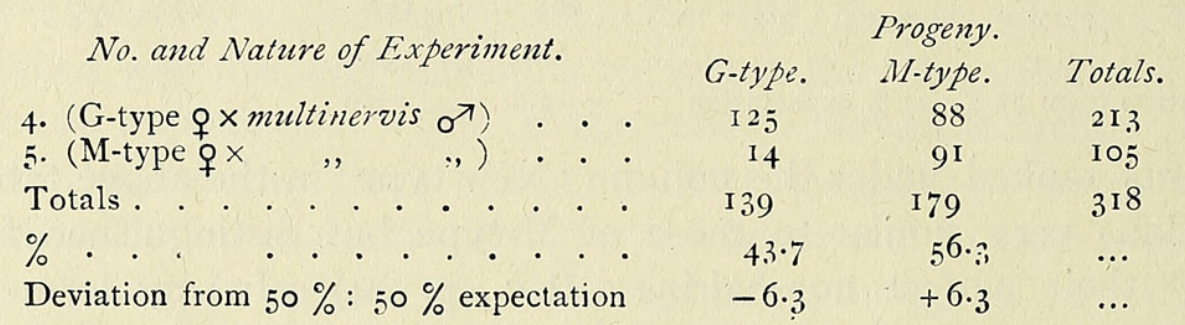

Since the segregation occurs according to $3: 1$ fashion, we expect to have in $D R \times R 50$ per cent. G-types and 50 per cent. M-types. Actually we have 43.7 per cent. of the former and 56.3 per cent. of the latter. The deviation is therefore $\pm 6 \cdot 3$, and is positive on the side of the M-type, just as was the case in $F_{2}$ (see Table III); this is evidently to be ascribed to the fact that in certain cases the usual dominance fails, i. e.-

$D R \times R R=(50-6 \cdot 3)$ per cent. $D R+6 \cdot 3$ per cent. $(D R)+50$ per cent. $R R=43.7$ per cent. G-type $+(6 \cdot 3+50)$ per cent. M-type $=43.7$ per cent. $\mathrm{G}$-type $+56 \cdot 3$ per cent. M-type.

$(D R)$ denotes, as before, the zygotes where dominance fails.

In the back-cross $D R \times D$ we have to distinguish between G-type $\times$ gracilistyla and M-type $\times$ gracilistyla. These crosses were performed in I9I9, and the results as studied in $192 \mathrm{I}$ are as follows:

TABLE V.

No. and Nature of Experiment.

6. (G-type $\wp \times$ gracilistyla $\left.\sigma^{\top}\right)$. .

7. (M-type $q^{\circ}, \quad,$, )...

Totals . . . . . . . . . . .

\% . . . . . . . . . . . . .

Deviation from $100 \%$ : $0 \%$ expectation

\begin{tabular}{ccc} 
& \multicolumn{2}{c}{ Progeny. } \\
$G$-type. & M-type. & New type. \\
I 84 & 8 & $\ldots$ \\
76 & 9 & II \\
260 & I 7 & I I \\
93.8 & 6.2 & $\ldots$ \\
-6.2 & +6.2 & $\ldots$
\end{tabular}

Totals.

192 96 288

$\ldots$

In the above table the new type is not taken into consideration for counting the percentage.

Since the above crosses correspond to $D R \times D$ we expect to have 100 per cent. G-types and no M-types at all. Actually we have $6 \cdot 2$ per cent. of the latter, so that the deviation from the theoretical expectation is $\pm 6 \cdot 2$, which is again positive on the side of M-type, i. e.-

$D R \times D D=50$ per cent. $D D+(50-6 \cdot 2)$ per cent. $D R+6 \cdot 2$ per cent. $(D R)=93 \cdot 8$ per cent. G-type $+6 \cdot 2$ per cent. M-type.

$(D R)=$ zygotes where dominance fails. 
If we compare the results shown in Tables III, IV, and V, we see that the deviations from the expectation are very similar to each other $(5 \cdot 6$ per cent., $6 \cdot 3$ per cent., $6 \cdot 2$ per cent. respectively), which will indicate that the degree of failure of dominance is nearly the same in all three cases. In $F_{1}$ generation, however, where the theoretical expectation is 100 per cent. dominants and no recessives, the deviation, i. e. the failure of dominance, is 16.7 per cent. (see Table II), and conséquently much larger than in the above three cases. To what cause may such a difference be ascribed? We may make several suppositions. Thus, for instance, in the crosses shown in Tables III-V one or both parents are heterozygous, i. e. $D R$, whilst in the cross in Table II both are homozygous; may not such a circumstance lead to the difference in the degree of failure of dominance? We may perhaps put forward another consideration: Does not that degree vary under the influence of external conditions? Such questions and all others which one may ask are naturally not to be definitely decided without further breeding experiments, and I must here be satisfied with simply indicating such problems.

A few words as to the dominance of the gracilistyla catkin. We have seen that the hairy condition of catkins of the latter is dominant to the less hairy condition of multinervis as a rule. I have observed that in multinervis $\times$ gracilistyla the non-hairiness of leaves is dominant to their hairiness (1. c., p. $3^{8}$ ), which is consequently very different from what we see in the catkins in the same hybrid. Evidently the genetic factors concerning hairs covering leaves on one hand and those covering catkins on the other must be quite different.

\section{Potency.}

As we can easily see by comparing the results of the various crosses above enunciated, the degree of failure of dominance is not the same in G-type as in M-type. The question is, Do the G-type plants produce a larger proportion of G-type progeny than the M-type ones, and vice versa? Is the degree of 'potency' (to use the word and the expression adopted by Davenport ${ }^{1}$ ) inherited ?

Let us first see what other authors have observed in this respect. In their experiment on the crossing between extra toes and normal ones in poultry, where the former are dominant to the latter, Bateson and

1 Carnegie Institution of Washington Publication, No. 121, 1909. The author says (p. 92), - The potency of a character may be defined as the capacity of its germinal determiner to complete its entire ontogeny. If we think of every character as being represented in the germ by a determiner, then we must recognize the fact that this determiner may sometimes develop fully, sometimes imperfectly, and sometimes not at all. ... Potency is variable. Even in a pure strain a determiner does not always develop fully.... Bnt in a heterozygote potency is usually more or less reduced. When the reduction is slight, dominance is nearly complete; but when the reduction is great. dominance is more or less incomplete....' 
Punnett ${ }^{1}$ have obtained, $(\alpha)$ from the heterozygote $D R$ with usual dominance $\times$ recessive, I I 4 extra toes and 9.5 normal, i. e. 54.5 per cent. and $4.5^{\circ} 5$ per cent. respectively, and $(b)$ from the heterozygote $D R$ where dominance fails $\times$ recessive, I 28 extra toes and I 5 I normal, i. e. 45.7 per cent. and $54^{\circ} \mathrm{I}$ per cent. respectively; consequently the class $(a)$ contains comparatively a little more extra-toed progeny than the class $(b)$. So that there may be a very slight inheritance of degree of potency, but this is quite insignificant. Much more marked inheritance has been found by Davenport ${ }^{2}$ in respect to the crosses of Houdan fowls: he has calculated the correlation between total number of toes in the two parents and average number of toes in their progeny, and found the coefficient of correlation to be equal to +0.683 \pm 0.092 .

Turning to our case, the simple inspection of the results of Expts. I, 3, 5, 6 shown in Tables III, IV, V, will immediately indicate to us that the inheritance of the degree of potency is very significant in the present case. The results of our four experiments just enumerated were employed to make the following table of correlation :

\section{TABLE VI.}

\begin{tabular}{|c|c|c|c|}
\hline Nature of Crosses. & $G$-type. & $\begin{array}{l}\text { Progeny. } \\
\text { M-type. }\end{array}$ & Totals. \\
\hline $\begin{array}{l}\text { G-type } \times \text { G-type and G-type } \times \text { gracilistyla } \\
(\text { Expts. I and } 6)\end{array}$ & $187+184$ & $32+8$ & 4I I \\
\hline $\begin{array}{l}\text { M-type } \times \text { M-type and M-type } \times \text { multinervis } \\
(\text { Expts. } 3 \text { and } 5)\end{array}$ & $4+14$ & $19+9 I$ & I 28 \\
\hline Totals . . . . . . . . . . & 389 & 150 & 539 \\
\hline
\end{tabular}

This gives $r=+0.724 \pm 0.021$. The coefficient or correlation is rather high, and this result confirms our supposition founded on mere inspection of data.

Since the appearance of the well-known work of Wichura ${ }^{3}$ it seems that botanists have generally believed in the constancy of Salix hybrids throughout later generations. In a short note Sirks ${ }^{4}$ has expressed his opinion that the work of Wichura by no means induces us to the belief that Salix hybrids are constant. In $1916^{5}$ and $1918^{6}$ I published the results of my investigations on the hybridization of some species of Salix, especially $S$. gracilistyla and multinervis : in these experiments I was able, contrary to the current belief of botanists, to observe the segregation of some few characters in Salix hybrids, but since the relative number

1 Reports to the Evolution Committee of the Royal Society. Report II, I905, p. II 5 .

2 1. c., p. 23 .

3 Die Bastardbefruchtung im Pflanzenreich erläutert an den Bastarden der Weiden. Breslau, 1865 .

4 Zeits. f. indukt. Abstamm.- u. Vererbungslehre, Bd. xv, I9I 5, pp. 164-5.

5 Bot. Mag., Tôkyô, vol. xxx, 1916, pp. 316-20.

6 Journ. of Genetics, vol. viii, I918, pp. 35-58. 
Ikeno.-On Hybridization of some Species of Salix. II. I ${ }_{3} 3$ of segregates was somewhat different from what we might have expected in the case of usual Mendelian segregation, I could not then decide definitely whether we have here really to deal with such or not. In I9I 8 HeribertNilsson ${ }^{1}$ published an elaborate memoir containing the results of his extensive experiments on Salix hybrids: he was able not only to prove the segregation of various characters, but also to discover the usual Mendelian ratio in many cases. My experiments concerning the catkin characters above mentioned have shown that their segregation occurs according to the simplest Mendelian ratio $3: \mathrm{I}$, though more or less obscured by the imperfection of dominance. Accordingly these experiments are a further contribution towards establishing the fact that the segregation of the various characters in Salix hybrids follows Mendel's law.

\section{iII. Formation of Parental Form.}

The hybridization multinervis $\times$ gracilistyla done in I9II has given rise to almost fifty offspring, all of which were, contrary to our expectation, not hybrids, but female multinervis. ${ }^{2}$

I have myself had no doubt about the actual production of multinervis progeny in this case. The fact was, however, so unexpected that others may reasonably be in doubt about its reality. So I repeated the same hybridization in 1918 and I9I9. The results of hybridization in I9I 8 are contained in Table I (see p. I76). Though, as is usually the case in this hybridization, each catkin has produced only few seeds-often none-yet I have obtained a comparatively large number of progeny-more than ninety plants in all ; but the number of multinervis was small-in fact I had only two (Table I, Nos. 26 and 29). On the contrary, the hybridization carried on in 1919 has yielded very few seedlings, but almost all were multinervis progeny, thus:

TABLE VII.

$\begin{array}{ccc}\begin{array}{c}\text { No. of the Female Parent } \\ \text { (multinervis q). }\end{array} & \text { No. of Catkins. } & \begin{array}{c}\text { No. of Progeny } \\ \text { (multinervis). }\end{array} \\ \text { I. } & 35 & 2 \\ & 36 & \text { I } \\ \text { II. } & 4 \mathrm{I} & \text { I } \\ & 4 & \text { I } \\ \text { Total } & 7 & \frac{4}{9}\end{array}$

Gracilistyla used as the pollen plant in the above experiments was the same in both cases, and identical with what we have employed in the experiments whose results are shown in Table I.

No progeny contained in the above table bear flowers yet, but that all of them are multinervis is quite unmistakable on account of their characteristic leaves, \&c. Besides them, some plants which are not multi-

1 Lunds Universitets Årsskrift, N.F., Afd. 2, Bd. xiv, No. 28, 1918.

${ }^{2}$ l. c., p. 5 I. 
nervis, perhaps hybrids, have been produced, but since they perished before flowering they are not enumerated in the table.

From the results just enunciated we now can have no reason to doubt the production of multinervis progeny from multinervis mother without the action of multinervis pollen.

It is well known that sometimes in some Salix species a few male flowers are produced on the female catkin, or even a few flowers become hermaphrodite. One might perhaps think that the production of multinervis progeny in our case might be due to such abnormalities which have escaped my attention. I have looked for them in our multinervis trees carefully and repeatedly: it may be remarked in this respect that $I$ have never met with even traces of such in our trees.

When my former paper was published the fact whether or no the multinervis progeny under discussion will breed true in later generations was not yet decided, though this seems to me to be highly probable. I pollinated in 1920 two such multinervis progeny (from Nos. 26 and 29 in Table I) by pollen taken from a multinervis male plant, and got a certain number of progeny. The latter were multinervis without exception, so that my supposition that they will breed true has been fully confirmed.

The next question will be, How are the multinervis progeny produced without the action of multinervis pollen? My conclusion in my former paper was that it may be ascribed neither to parthenogenesis nor to development of nucellar cells, but to so-called pseudogamous development of oospheres due to the stimulus of foreign pollen (1. c., pp. 5I-4). Some doubt, however, arose in my mind in 1919 about this conclusion. Mr. S. Nohara, then assistant in my laboratory, covered a number of young catkins of a tree cultivated in our botanical garden, and very similar to multinervis, ${ }^{1}$ with paper-bags for a certain purpose, and left them in this condition for a certain lapse of time, perhaps about two months. On opening them he was struck by the fact that some catkins had produced a few fruits. He notified me of the fact. I placed some seeds thus obtained upon a moist filterpaper within a Petri dish : some of them were so weak that they refused to germinate, but others germinated very well. Still others were sown in a seed-pan and came to germination. ${ }^{2}$ From all these facts there will be no doubt about the occurrence of the 'apomictic' development without any pollination in this case, to use the word introduced by the German botanist Winkler. ${ }^{3}$

It may be a variety of multinervis; it is chiefly distinguished from the latter by its smaller catkins.

2 Plants derived from this germination are now cultivated in our garden. So far as we can judge by their leaves they are quite similar to their parent ; one of them has already borne female catkins, and proved itself to be perfectly similar to its parent.

3 Parthenogenesis und Apogamie im Pflanzenreiche, Jena, 1908, pp. $8 \mathrm{ff}$. 
In my former paper I stated the fact that female inflorescences of multinervis covered with paper-bags were never able to bear fruits. ${ }^{1}$ This is quite true, but then only a few branches were used for the experiment. In view of the results obtained by $\mathrm{Mr}$. Nohara, which are described above, the experiments were repeated in 1920 and $192 \mathrm{I}$ on a much larger scale than formerly. In I 920 nine trees were chosen for the experiment : of these, three (Nos. I-3 in Table VIII below) which are high and copiously branched are derived from the fertilization inter se of male and female trees used in my experiments done in I9IO and I9II; the remaining six are smaller, of which four (Nos. 4-7 in Table VIII) are the cuttings from a female tree used in the same experiments, and two are from Nos. 26 and 29 in Table I (i. e. plants produced without the action of multinervis pollen), designated in Table VIII as Nos. 8 and 9. The number of catkins in each tree was as follows :

\section{TABLE VIII.}

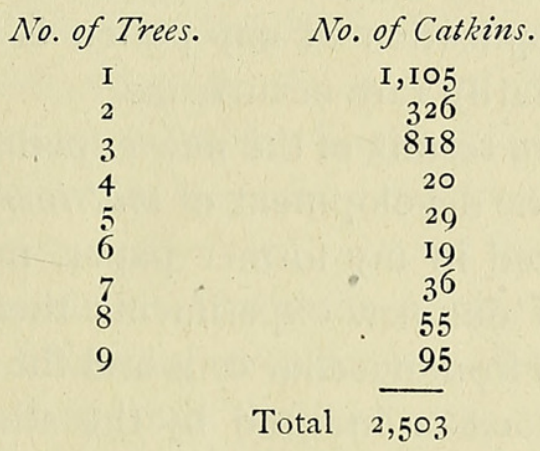

If we suppose that each catkin bears 100 flowers on average, and each flower contains three ovules, both of which are by no means high estimations, we should have a total of $75^{\circ}, 900$ ovules. All catkins enumerated in the above table were covered with paper-bags, and left in this condition for nearly two months. Though in certain catkins a few ovaries grew up somewhat more intensely than others, and consequently attracted our attention by their remarkable size, yet all of them, on opening, were found either to be quite empty or to contain a few seed-hairs only. All other catkins simply dried up and fell, with the exception of two catkins from No. 8 in the above table. Thus only from the latter did I get four seeds in all. Of these, two, being placed upon a moist filter-paper within a Petri dish, came to germination, whilst the remaining two did not.

Similar experiments were repeated in $192 \mathrm{I}$ on the same nine trees used in I920. The number of catkins produced in I92I was somewhat smaller than in 1920 ; besides, either a certain number of branches covered with bags were broken down, or the latter were torn off by storms which

$$
1 \text { l. c., p. } 54 \text {. }
$$


raged several times in March and April. As catkins on such branches must necessarily have been left out of consideration, the number of those available for our experiment was considerably diminished. Nevertheless, we had 1,26I catkins which should contain no less than $1,261 \times 100 \times 3$ $=378,300$ ovules in all, i.e. more than half the number of ovules experimented upon in 1920. All these catkins were covered with bags for more than two months. As in the former year I saw not unfrequently ovaries which grew somewhat more intensely than others, but generally they either simply shrivelled up gradually, or opened and proved themselves to contain no seeds at all. Only on some catkins of the tree designated as No. I in Table VIII did I get eight seeds. Of these, three came to germination, and one began to germinate but soon ceased to make any further growth. All remaining seeds refused to germinate.

In the two new experiments just mentioned I was thus able to get only very few seeds which have the power of germination, but nevertheless they have proven beyond all doubts that in our case the apomictic development of ovules without the application of any pollen is a matter of possibility, though it is of extraordinarily rare occurrence.

In consequence of the results of the new experiments just described my former view concerning the development of multinervis after the pollination with gracilistyla, as stated in my former paper, must necessarily change. To explain the result of our new experiments there are two possibilities, viz. the embryo formation from nucellar cells and the parthenogenesis, each of which is either autonomous or induced by the stimulus of foreign pollen. The definite conclusion whether the apomictic development in question will occur according to the first or the second mode just enunciated would naturally be possible only after a comparative cytological examination of the development of normal as well as apomictic ovules. Since, as above stated, ovules of the latter class are of extremely rare occurrence, it would be necessary for the purpose to examine innumerable specimens made by sectioning an enormous number of catkins, and even then there would be no great chance of meeting with such ovules. Thus we see that in the present case the cytological examination must be almost an impossibility. The embryo formation from nucellar cells is generally accompanied by polyembryony, as in Funkia, Citrus, Opuntia, \&c., \&c. Since I have never met with this in Salix, although I have observed the germination of many thousand seeds of various species of Salix, either pure or hybrid, including $S$. multinervis, I am rather inclined to the view that as the cause of apomictic development in our case parthenogenesis is much more probable than embryony. All the following discussion is accordingly founded on the supposition that we have here to deal with parthogenesis, either autonomous or induced. 
In Thalictrum purpurascens ${ }^{1}$ as well as some species of Hieracium (pilosella, excellens, \&c.) ${ }^{2}$ it is well known that there are two kinds of ovules, viz. those which require fertilization for seed formation, and those which do not. It will naturally be quite the same in Salix multinervis. As we have here to deal in all probability with somatic parthenogenesis in the sense of Winkler, ${ }^{3}$ it follows that the former kind of ovules, which have undergone the reducing division of chromosomes during their development, become hybrids by pollination with foreign pollen, while the latter kind, which have undergone no such process, develop to multinervis without being fertilized. Moreover, that these two kinds of ovules are contained at the same time not only in one plant individual, but also in one and the same catkin, is clearly seen from the examination of No. 26 in Table I (see p. I76), inasmuch as in this number the progeny which are derived from one single catkin contain, besides one multinervis, four G-types (i. e. hybrids).

In my former paper I was led to the conclusion that in our case we have to deal with pseudogamy, i.e. parthenogenesis induced by the stimulus of foreign pollen, gracilistyla in the present case. This was the natural consequence deduced from the results of my former experiments, because then any catkin covered with a bag was found not to be able to bear a single seed. Since, however, our new experiments have shown us that in certain cases, though extremely rare, catkins wholly prevented from any pollination are able to produce a few seeds, my former conclusion is of course not quite right. The following remarks may, however, be made in consequence of the results of our new experiments. Although very rarely, the apomictic development without any pollination is possible, yet we have seen that the number of seeds then produced was so scanty that pseudogamy might also be not impossible in certain cases. For instance, in our experiment done in $19 \mathrm{II}$, where the pollination with gracilistyla was several times carried on, I have got almost fifty multinervis individuals from a few catkins, while in the experiments done in 1920 and I92I, when no such pollination was practised, only five apomictic seeds which were able to germinate were obtained out of more than $700,000+370,000=1,070,000$ ovules! ${ }^{4}$ It is not improbable that although few ovules may develop parthenogenetically without the stimulus of foreign pollen (autonomous parthenogenesis), yet ovules may in many cases be induced to

1 Overton: Bot. Gaz., vol. xxiii, I902, pp. $363-75$; Ber. d. Deutsch. Bot. Ges., Bd. xxii, I904, pp. $274-93$.

2 Ostenfeld : Botanisk Tidsskrift, Bd. 27, 1906, pp. 225-48. Rosenberg: ibid., Bd. xxvii, I907, pp. I $43-70$.

3 1. c., p. 17 .

4 In the experiment carried on in 1919 , when the pollination by gracilistyla was practised, I got only nine multinervis (see Table VII), but then only a very few catkins were used for experiment, and it is hardly doubtful that had I experimented upon a larger number of catkins I should have been able to obtain a much larger multinervis progeny. 
development only by its stimulating action (pseudogamy). As before stated, I have observed frequently in catkins covered with bags ovaries which have grown up somewhat more intensely than others and yet remain quite sterile; may not such ovaries be able to produce some seeds by the stimulus of foreign pollen? This is, however, a mere supposition, and the fact ought to be studied in future more in detail, because it is quite possible that exceptionally a much larger number of ovules than I was able to observe in my experiments might develop to seeds without any pollination.

The results of experiments of Pellew and Durham with Primula verticillata, floribunda, and the hybrid between them, $P$. Kewensis, ${ }^{1}$ agree in several respects with what I have seen in our Salix. It appears that they have also met with autonomous as well as induced parthenogenesis, for they say, "We incline to suppose that the ovules are such that while they can occasionally develop without fertilization they more commonly develop in consequence of that stimulus.'

Concerning the above experiments of Pellew and Durham, Winkler makes the following remarks, which are reproduced below in his own words : - Vor Allem aber ist ... zu bedenken, dass die apomiktische Samenbildung auch ohne jeden Bestäubungsreiz erfolgen kann, so dass ein solcher als Auslösung der vermuteten Parthenogenesis jedenfalls nicht unentbehrlich sein, sondern höchstens fördernd wirken kann. Dann kann man aber auch nicht von einer durch die Bestäubung induzierten Parthenogenesis sprechen ... sondern nur davon, dass durch den Pollenschlauchreiz die an sich schon vorhandene Neigung zur apomiktischen Samenbildung gefördert wird. ... ${ }^{3}$ All that Winkler says may be true, and also applicable to our case of Salix. To decide, however, experimentally the fact whether pollination has induced parthenogenesis, or has simply accelerated ('fördern ') the tendency for apomictic development, would not be easy.

Had we to deal in our case with parthenogenesis, either autonomous or induced, the following remark might not be without some interest. It is clear that parthenogenesis has been originally derived from normal fertilization in the course of phylogenetic evolution. In respect to the manner of its origin there may be two possible ways. Firstly, certain animal or plant forms which have reproduced themselves at first by normal fertilization acquire at once the power of complete parthenogenesis by mutation, so that all eggs or ovules reach suddenly a condition such that they need no fertilization for their further development. Secondly, the transition from fertilization to parthenogenesis is gradual, i. e. several stages intervene between the two extremes-as we see, for instance, in some

1 Journ. of Genetics, vol. v, 1916, pp. I 59-82.

2 1.c., p. 160.

3 Ursache und Verbreitung der Parthenogenesis im Pflanzen- und Tierreich, Jena, I920, p. I75. 
animals, as Rhabditis aberrans (Nematoda) studied by Krueger. ${ }^{1}$ Thalictrum purpurascens as well as certain species of Hieracium, where some ovules are parthenogenetic and others normal, may be considered to be in their way of this transition. ${ }^{2}$ Our Salix multinervis is also to be ranked among such transitional forms, and in view of the extreme rarity of parthenogenetic ovules, as well as of the fact that parthenogenesis is not always autonomous but in many cases induced (considering my supposition above expressed to hold good), we may regard our Salix as being in the very beginning of such transition.

The opinion was expressed by some authors that parthenogenesis has taken its origin in consequence of the abortion of pollen and the decline of sexuality, while that of others, especially Winkler, is quite opposed to it. ${ }^{3}$ Now if such were really the case we should also observe such phenomena in our Salix, but we can there recognize neither abortion of pollen nor decline of sexuality. For instance, Nohara has examined the germinating power of pollen of our Salix by the use of 2-3 per cent. cane-sugar solution, and found it to be as high as 98 per cent. ${ }^{4}$ I asked him to examine the germinating power of seeds of this Salix species, and he found that out of 721 seeds, taken from four catkins artificially pollinated by a male plant of the same species, 655 came to germination, i.e. $92 \cdot 2$ per cent. The results of these observations are obviously decidedly in favour of the opinion of Winkler.

We come finally to the problem of the sex of our apomictic progeny. As before stated, nearly fifty mulinervis individuals resulting from the experiment in I9I I were female without any single exception; so also were two multinervis obtained by the pollination done in 1918 (cf. Nos. 26 and 29 in Table I). The sex of nine multinervis derived from the pollination made in 1919 (Table VII) is yet unknown. In view of the small number of the multinervis progeny resulting from the experiment of 1918 , we are not able to make any inference about them, but the fact that all multinervis offspring derived from the experiment of I9I I, numbering almost fifty, are female can hardly be without a certain significance. Before going farther, let us see first what we know about the sex of the progeny arising by parthenogenesis in animals and plants. In the former it is arrhenotokous (males produced exclusively), thelytokous (females produced exclusively), or amphiterotokous (both males and females produced) in different. cases. ${ }^{5}$ Concerning a few dioecious plants where natural parthenogenesis has been discovered, the sex of the progeny arising by this process is known in

1 Cf. Winkler, 1. c., pp. $28 \mathrm{ff}$.

2 Certain species of $R u b u s$ may also belong to such transitional form. (Cf. Lidforss, Zeits. f. indukt. Abstamm.- u. Vererbungslehre, Bd. xii, I9I4, pp. 1-r3).

3 Parthenogenesis und Apogamie im Pflanzenreich, pp. $133 \mathrm{ff}$.

4 Bot. Mag., Tôkyô, vol. xxvii,.1913, p. 185.

5 Cf. Winkler: Ursache und Verbreitung der Parthenogenesis, p. 15. 
some cases. Thus, for instance, in Bryonica dioica Bitter has obtained nine parthenogenetic plants, all of which were male. ${ }^{1}$ In. Thalictrum purpurascens the sex of the progeny due to this process is not specially mentioned. ${ }^{2}$ In Antennaria alpina males are very rare, and parthenogenesis seems to be chiefly thelytokous. ${ }^{3}$ In Chara crinita, known long since as the classical example of natural parthenogenesis in plants, Ernst ${ }^{4}$ has recently discovered that there are two strains: in one, which reproduces itself by normal fertilization, males and females are produced in almost equal number, whilst in the other, which reproduces itself by parthenogenesis, plants are exclusively female, i.e. parenthogenesis is thelytokous. Since in our Salix species our repeated observations have proved that even in the case of normal fertilization females are much superior in number to males, the fact above enunciated, that all fifty offspring are female, might be due simply to the latter circumstance, inasmuch as had we had more than fifty plants it would have been possible that some male offspring might have been obtained. If, however, parthenogenesis in our Salix should prove really to be thelytokous, the fact is easily comprehensible, whether the female is homozygous or heterozygous in respect to the sex-determining factors; because, since in our case egg-cells are supposed to develop without undergoing any reducing division of chromosomes, they will remain always in the state of the so-called female-producing ones, $X X$ in the first case and $W Z$ in the second according to the wellknown nomenclature of Morgan.

\section{Summary.}

I. By pollination of Salix multinervis by $S$. gracilistyla we get hybrids, as well as multinervis exactly similar to the mother-plant.

2. Two kinds of hybrids appear in $F_{1}$. The one characterized by its densely hairy catkin is called $G$-type; the other characterized by its less hairy catkin is called $M$-type, and is produced in much less number than the other (for instance, 17 per cent. against 83 per cent. in round numbers). Though the two differ externally they are genetically equivalent.

3. From the study of various crosses we are led to the conclusion that the hairy catkin of gracilistyla is dominant as a rule to the less hairy one of multinervis. If we represent them by $D$ and $R$ respectively the $F_{1}$ progeny agree in being $D R$.

4. That in $F_{1}$ some $D R$ individuals are G-type and others M-type is due to the imperfection of dominance: in a few cases dominance fails,

1 Abhandl. d. Naturwiss. Vereins zu Bremen, Bd. xviii, Heft I, I904. Original not seen.

2 Overton, 1. c.

3 Juel : Kongl. Svenska Vetenskaps Akademiens Handlingar, Pd. xxxiii, I900, p. II.

4 Bastardierung als Ursache der Apogamie im Pflanzenreich, Jena, IgI8. Cf. especially chapter iii, pp. $49 \mathrm{ff}$. 
and the recessive character appears externally, giving rise to M-types. The appearance of two types in $F_{1}$ is not to be regarded as Mendelian segregation.

5. The segregation occurs first in $F_{2}$ as usual. The $F_{2}$ generation resulting from the cross between the $F_{1}$ progeny is variously composed: G-type $\& \times$ G-type $\sigma^{r}$ produces chiefly G-types and a few M-types, M-type $q \times$ M-type $o^{7}$ chiefly M-types and a few G-types, M-type $q \times$ G-type $o^{\top}$ both types in almost equal number.

6. If we add the results of the above three crosses together we find that we have G-types and M-types in the approximate proportion of $3: 1$, with a certain positive deviation on the side of the latter type: this deviation is due to the imperfection of dominance of the factor $D$ in relation to the factor $R$.

7. The above conclusion has been fully confirmed by the results of back-crosses, either $D R \times R$ or $D R \times D$.

8. The degree of potency is inherited: i.e. G-type plants produce a much larger proportion of G-type progeny than do M-type plants, and vice versa.

9. Rarely multinervis $\times$ gracilistyla gives rise to multinervis progeny which breed true in later generation. Their production from a multinervis mother without any pollination at all has been also observed, though very rarely. Whether the embryo formation from nucellar cells or parthenogenesis is the real cause of such 'apomictic' development is not definitely established.

IO. We have here to deal with parthenogenesis, which is very occasionally autonomous; in many other cases, however, it seems possible that it is induced by the stimulating action of foreign pollen (pseudogamy).

II. If parthenogenesis is derived phylogenetically from normal fertilization, and if this transition is gradual, our Salix multinervis may perhaps be regarded as being in the way of such transition, and in its very beginning.

I2. Neither abortion of pollen nor decline of sexuality is to be detected in our Salix, which contradicts the view often expressed that parthenogenesis sets in in consequence of such circumstances.

13. All plants of multinervis produced by apomixis are female, without any exception. The explanation for it is given.

All expenses needed for carrying out the experiments contained in this paper were partly defrayed out of grants from the Department of Education and the 'Keimeikwai' (a society whose object is to give pecuniary assistance to scientific investigators, \&c., \&c.) in Tôkyô. 


\section{$2 \mathrm{BHL}$ Biodiversity Heritage Library}

Ikeno, S. 1922. "On hybridization of some species of Salix. II." Annals of botany 36, 175-191. https://doi.org/10.1093/oxfordjournals.aob.a089792.

View This Item Online: https://www.biodiversitylibrary.org/item/234428

DOI: https://doi.org/10.1093/oxfordjournals.aob.a089792

Permalink: https://www.biodiversitylibrary.org/partpdf/319035

\section{Holding Institution}

Smithsonian Libraries

\section{Sponsored by}

Biodiversity Heritage Library

\section{Copyright \& Reuse}

Copyright Status: Not in copyright. The BHL knows of no copyright restrictions on this item.

This document was created from content at the Biodiversity Heritage Library, the world's largest open access digital library for biodiversity literature and archives. Visit BHL at https://www.biodiversitylibrary.org. 